\section{Brand reputation and relationship with customer loyalty in the retail pharmacy sector: A case study}

\author{
Péricles Ewaldo Jader Pereira ${ }^{1}$ \\ Carlos Marcelo Ardigó ${ }^{2}$ \\ Pablo Flôres Limberger ${ }^{3}$
}

\begin{abstract}
Purpose - This study aims to evaluate the relationship between the reputation of the retail brand and customer loyalty in the retail pharmacy sector.

Theoretical framework - This article is based on the relationship between customer loyalty and brand reputation. It uses some of the brand reputation variables from the brand equity model (Aaker, 1991) to arrive at an explanatory framework that can differentiate key variables for the most frequented retail pharmacy brands to remain in the market, as well as the differentials of the most frequented retail pharmacy brands.
\end{abstract}

Design/methodology/approach - To achieve the objective of the study, exploratory factor analysis and linear multiple regression were used as the analysis techniques. A survey was carried out to collect data from 469 retail pharmacy customers in a municipality of Santa Catarina, located in the South Region of Brazil. The sample is non-probabilistic.

Findings - The results suggest that popularity, level of knowledge, and familiarity significantly and positively affect loyalty to the most frequented brands. In the case of the least frequented ones, level of knowledge and familiarity have a significant and positive impact on loyalty to the brand. These findings reveal different perceptions regarding the most frequented and the least frequented pharmacies. However, the most relevant aspects remain the same regardless of how frequented the retail pharmacy is.

1. Regional University of Blumenau, Master in Administration - Management, Internationalization and Logistics, Balneário Camboriú, Brazil

2. University of Vale do Itajai, Professional Master's Program in Administration Management, Internationalization and Logistics, Itajai, and Master and PhD in Tourism and Hospitality, Balneário Camboriú, Brazil

3. University of Vale do Itajai, Master and PhD in Tourism and Hospitality, Balneário Camboriu, Brazil

How to cite:

Pereira, Péricles, Ardigó, Carlos, Limberger, Pablo. Brand Reputation and Relationship with Customer Loyalty in the Retail Pharmacy Sector: a Case Study. Revista Brasileira de Gestão de Negócios, 23(3), p.557-570.
Received on:

07/03/2019

Approved on:

$10 / 01 / 2020$

Responsible Editor:

Prof. Dr. Guilherme Shiraishi

\section{Evaluation process:}

Double Blind Review

\section{Reviewers:}

Angilberto Sabino Freitas; Wilian Ramalho Feitosa; Maria Jesus Yague

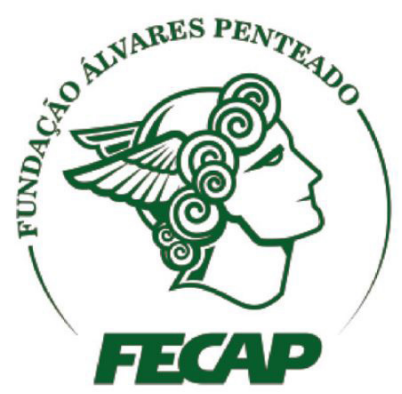

Revista Brasileira de Gestáo de Negócios

https://doi.org/10.7819/rbgn.v23i3.4120 
Practical \& social implications of research - Theoretically, the study has positive implications as it demonstrates the items that have the greatest and least impact in terms of brand reputation and customer loyalty. As practical implications, this study can help pharmacy managers to choose and better focus their strategies. As for social impacts, it was noted that brands that are considered to be less frequented have a lower level of loyalty, which was expected; however, this loyalty is more constant than for more frequented brands.

Originality/value - This study contributes to the advancement of research involving brand reputation and customer loyalty in retail, especially in the pharmaceutical sector.

Keywords - customer loyalty, brand reputation, retail pharmacy.

\section{Introduction}

The business environment has become increasingly dynamic, fast-changing, and thus challenging (Hermes, Cruz, \& Santini, 2016; Molina \& Ampudia, 2018; Scussel $\&$ Demo, 2016). In this context, organizations have begun to develop more aggressive and innovative strategies to remain competitive. Silva, Vasconcelos, Jeunon, and Duflot (2016) point out that in order to succeed in this environment many organizations focus on learning about the market and gathering information to gain a competitive advantage. The same applies to retailers in general; however, in the case of retail pharmacies we must consider other factors as well, such as state control, regulatory boards, or professional associations, and the high level of commoditization of products (Freitas, 2006; Gabriel, Pelissari, \& Oliveira, 2013; Pereira \& Bastos, 2009).

The retail pharmacy segment is characterized by fierce competition. According to data from the Federal Council of Pharmacy (CFF) (2018), the number of pharmacies per 10,000 inhabitants in Brazil is 3.99; however, the World Health Organization (WHO) (2017) indicates that the ideal ratio is one unit per 10,000 inhabitants. Therefore, the Brazilian ratio is almost four times higher than the one recommended by the UN agency.

The CFF also reports that the sector is dominated by 23 large pharmacy chains, which between 2007 and 2017 increased their total market share from $42 \%$ to $59 \%$. On the other hand, the share of small chains and independent pharmacies decreased from $55 \%$ to $25 \%$. This reduction is mainly due to the characteristics of small and medium-sized businesses in the sector, which have limited capital, and thus, low competitive power (CFF, 2018).

In light of this highly competitive environment, in which similar products and difficulties are encountered, and there is a need to better understand the market to support future strategic decisions, this study aims to evaluate the relationship between the reputation of the retail pharmacy brand and customer loyalty.

Despite its importance and scientific scope, Fetscherin and Usunier (2012) mention in their study that there is a research gap to be investigated in corporate branding studies, since apparently only large multinational organizations are used to illustrate or exemplify research in the field of corporate brand management. Thus, the theoretical justification for this study lies both in the lack of studies on small business branding, as well as in the relationship between retail pharmacy brand reputation and customer loyalty.

From a practical point of view, this study is a useful tool for managers in the retail pharmacy sector and in retail in general who face strong competition and similarity of products. There is increasing evidence that a strong corporate brand can result in competitive advantages. In order to build a strong corporate brand, it is necessary to manage reputation (Parker, Lehmann, Keller, \& Schleicher, 2018)

In the following section we present the theoretical basis that supported this study. This is followed by the method adopted in the study, and then we present the results, discussion, and final considerations.

\section{Brand Reputation}

In a holistic way, Aaker (2012) considers a brand as being a living entity that relates to consumers and is understood as an amalgam of attributes (real or illusory, rational or emotional, tangible or invisible) that can generate satisfaction. For Kotler and Keller (2013), brands can differentiate products based on the performance of the product in a functional, rational, or tangible way. They can also portray symbolic, emotional, or intangible differences relating to what the brand represents or its abstract meaning. 
For retailers, brands also perform several important functions, as they can generate consumer interest, preference, and loyalty to a particular store, in addition to creating in consumers expectations regarding offers and products. The quality of a retailer's services may also be tied to its own brand (Mukerjee, 2018).

Corporate brand reputation management cannot be pushed into the background as companies can no longer control what is said about them. This situation can be reflected in several ways since consumers can often form opinions about a company without ever having had any direct interaction with it. In this case, these opinions or perceptions are simply based on second-hand information and third-party experiences (Feldman, Behamonde, \& Bellido, 2014; Foroudi, 2019).

Reputation can apply to both individuals and organizations and represents a fragile intangible asset because it refers to the perception that others have about something (Foroudi, Dinnie, Kitchen, Melewar, \& Forundi, 2017; Srour, 2003). In the case of a company and corporate brand reputation, this reflects customers' and stakeholders' perceptions about it. Golgeli (2014) defines it as the total set of individual and collective judgments about the reliability of an institution based on a general set of values, its trustworthiness, and competence.

Reputation is one of the factors considered to assess brand equity according to the Brand Asset Valuator (BAV) model, which is one of the most widely accepted. This model was developed by the advertising agency Young \& Rubicam (Y\&R) based on a survey of 800,000 consumers in 51 countries (Aaker, 2009; Gerzema, Lebar, \& Rivers, 2009; Kotler \& Keller, 2013; Ramos, 2014; Sasikala, 2013; Srivastava, Arora, Lakhotia, \& Tripathy, 2015).

According to Gerzema et al. (2009), the BAV model converts a company's data on global consumers' perceptions and behavioral patterns into assessments of brand strength and value. For Srivastava et al. (2015), the BAV provides a realistic overview of brands since it measures their value in people's hearts and minds. The model considers two measurement categories. The first is brand stature or reputation, which mirrors the past performance of the brand and is measured by esteem, including customers' perceptions and loyalty; and knowledge, which means awareness of the brand and the experience consumers have with the brand. The second is brand strength, which is an early indicator of how far the brand will go in the future and is measured by consumers' perceptions about brand differentiation and relevance. However, in this study, we focus specifically on the reputation dimension (category of measurement), defined through its determinants: esteem and knowledge. A good reputation, from a strategic point of view, can be an asset of great value for organizations to differentiate themselves from competitors in their segment, as well as creating barriers to the entry of new competitors (Feldman et al., 2014). Reputation is the result of behavior developed over the years and describes the ability to create value for customers and other stakeholders. It is strongly linked to trust and legitimacy arising from stated policies or actions carried out. In several situations, the concept of reputation coincides with that of judgment or credibility (Fonseca, 2015; Foroudi, 2019)

Knox and Bickerton (2003) argue that the brand of a company reflects its actions and its format. A corporate brand is the visual, verbal, and behavioral expression of the unique business model of an organization. Thus, the understanding of reputation and brand reputation is practically inseparable. According to Balmer (2012) and Foreman and Argenti (2005), a corporate brand represents a link, i.e., an alliance between the company, its customers, suppliers, and other stakeholders. In the same vein, Hamzah, Alwi, and Othman (2014) point to the fact that a corporate brand's promise and value lends credibility in the eyes of customers.

In addition to customers, there are other actors involved in an organization, and therefore with its brand, including customers, employees, suppliers, and even competitors, which influence and are influenced by the actions and decisions of that organization. As they are affected by these actions, the stakeholders can act in selfdefense or in retaliation (Feldman, et al., 2014; Fonseca, 2015; Foroudi, 2019; Golgeli, 2014).

The combination of esteem and knowledge indicates brand status and scope, which can be a strong strategic indicator as it reflects current brand strength (Ramos, 2014). This combination of brand esteem and knowledge form the construct of brand reputation.

Esteem is a measure of brand association related to the cognitive and affective memories of each consumer, and it measures consumers' feelings towards a brand in its segment (Louro, 2000). Aaker (2012) mentions that esteem combines perceived quality with the perception of an increase or decrease in popularity. In general, esteem comes from perceived quality. However, the author points out that there are brands for which popularity ends up affecting esteem, but depending on the place, popularity may be more important than perceived quality. 
Johansson and Ronkainen (2005) argue that esteem is reached only after the brand has become familiar to consumers. Gerzema et al. (2009) reinforce that esteem is evaluated using the metrics of respect, perceived quality, and reliability, and it is generally considered to be an antecedent of loyalty and fidelity. It is the consumer's perception of brand quality and how much it is respected.

Esteem allows for an assessment of consumers' feeling towards and trust of a brand (Machado, 2010; Ramos, 2014), and the extent to which they need the brand (Ramos, 2014). Sampaio (2017) reports that esteem is measured by two factors: the perception of quality and popularity. According to Sasikala (2013), esteem measures how well the brand is regarded and respected, and if the brand keeps its promises. However, the proportion of these factors differs from country to country and from culture to culture, as mentioned by Ramos (2014) and Sasikala (2013).

In addition to brand esteem, another determinant of reputation is brand knowledge, which indicates that the consumer not only knows the brand but also understands what it stands for. For Ramos (2014), the customer's relationship with what the brand represents is measured by knowledge. This is important to verify how well consumers know the brand, and what their relationship is with it.

Gerzema et al. (2009) believe that knowledge is the peak and consequence of brand building and reflects the depth of the consumer's experience with the brand. Machado (2010) states that knowledge encompasses the consumer's understanding of the brand and the extent to which they internalize what the brand represents. Or, as Kotler and Keller (2013) put it, it covers the consumer's brand familiarity and knowledge.

For Sasikala (2013), knowledge is the extent of the consumers' awareness of the brand and understanding of its identity; that is, the levels of awareness about the brand and the intimacy consumers share with the brand. The true knowledge of the brand is the outcome of brand-building. Knowledge means being aware of the brand and understanding its purpose and what it stands for. Knowledge is not only achieved through the media; it cannot be bought, it must be achieved. Freitas (2012) argues that brand knowledge is key in the process of choosing between several alternative brands; the greater the knowledge, the greater the chance of being remembered, and thus, chosen.

Knowledge, unlike awareness, cannot be built through exposures alone; instead it is necessary to develop genuine customer intimacy with the brand. Knowledge can be placed in a five-tiered hierarchy that includes brand ignorance, brand recognition, brand recall, top-of-the mind brand, and dominant brand. Even if marketing spending is reduced over time, a brand with strong recognition tends to remain in the consumer's mind (Aaker, 2014).

Comparing brand esteem with brand knowledge often provides some important insights, because some brands rank higher in esteem than in knowledge (Sasikala, 2013). That means that relatively few people understand what the brand stands for, but those who do hold the brand in high regard. In this context, the brand has potential, which may or may not be realized, provided it finds a way to expand knowledge (Aaker, 2014). The author also points out that, conversely, a brand may have high knowledge but low esteem. This means that many consumers know what the brand stands for, but few hold it in high regard.

\section{Customer Loyalty in the Retail Pharmacy Sector}

Relationship marketing contributes to business success by improving performance, encompassing the aspects of customer satisfaction and loyalty, and thus representing a competitive advantage, if well used, according to Demo (2014) and Morgan and Hunt (1999) and Samawi (2017). Payne (2006) indicates that companies are shifting their marketing focus from customer acquisition to retention and loyalty.

Customer loyalty is understood as a commitment to consciously reacquire, or at least a tendency to reacquire, products or services in the future. In order to increase repeat purchases, companies must understand their customers' needs so as to create proximity and trust and thus drive customer loyalty (Kotler, Browen \& Makens, 1999; Oliver, 2014; Pinheiro, 2006; Santos \& Anjos, 2018).

In the same vein, Reichheld and Schefter (2000) and later Zeithaml, Bitener, and Gremler (2014) described the benefits of winning customer loyalty: the costs of serving loyal customers are lower; loyal customers are less price sensitive; they spend more time with the company; and they pass on positive recommendations about their favorite brands. The latter authors emphasize that customer loyalty means adding additional value to satisfaction in using a product or service. Loyal customers associate a company or a brand with a positive, almost familiar, feeling. 
Loyal customers not only purchase brand products and services frequently, but also play a major role as brand advocates. This is because when they have a strong relationship with the brand they are more likely to talk about it to their family and friends. This word-of-mouth communication has a great effect, as consumers highly value the opinion of those around them who constitute their reference groups (Pereira \& Bastos, 2009; Santos $\&$ Anjos, 2018).

Over the years, as mentioned by Melo (2012), some models have been applied to different market segments and countries with the aim of measuring customer satisfaction and loyalty. According to Fornell, Johnson, Anderson, Cha, and Bryant (1996), the Swedish Customer Satisfaction Barometer was created in 1989 as a tool for companies to evaluate their performance and try to gain loyalty, as well as achieving customer satisfaction.

Melo (2012) also points out that, based on this model, others have been proposed, such as American, Norwegian, and European models. When Johnson, Gustafsson, Andreassen, Lervik, and Cha (2001) revisited the proposed model, they repositioned consumer loyalty as the key dependent variable in the model, pointing out that it can be directly influenced by price, by the way complaints are handled, and by satisfaction. However, the indirect effects of these first two drivers on customer satisfaction include two aspects of relationship commitment: affective and calculative.

In the specific case of corporate image, this is established based on the recent experiences of consumers and their satisfaction with the company or brand. So the corporate image should be modeled as a result and not as a satisfaction factor. The effect of satisfaction on the corporate image reflects both the degree to which customer purchases and consumer experiences enhance the corporate image of a product or provide consistency of customer experiences over time (Johnson et al., 2001). The impact of image, in the context of retail, is portrayed in other studies as having a positive effect on consumer loyalty (Thomas, 2013) and on obtaining other competitive advantages (Fernandez, Lara, Ugalde, \& Sisodia, 2018).

In the case of the retail pharmacy and drugstore sector, customer loyalty is a major challenge, mainly due to the dominant presence of large retail chains and similar tangible products. The study by Pereira and Bastos (2009) highlights that in the current retail pharmacy sector, in which there is a strong appeal of brands, and a multitude of companies that produce different products and offer a wide range of services (home delivery, blood pressure and glucose measurements, among others), building loyalty strategies to gain and retain customers is essential to maintain market share and hold a position against competitors.

In the context of customer loyalty to pharmacies and drugstores, the authors found that there are important factors that influence the decision-making process of consumers, such as convenient location and easy parking. Although urban problems such as traffic are no longer exclusive to major cities, it should be considered that the authors conducted their study in a large metropolis, possibly making convenient location a determining factor. However, factors such as low price are also an important reason for choosing a pharmacy or drugstore (Pereira \& Bastos, 2009). This is confirmed by the studies of Bell (2014) and Kumar, Anand, and Song (2017), which also mention that despite changes in the retail context, the physical location of retail remains one of the most important factors for the success of the business.

Gabriel et al. (2013) evaluated the possible relationships between service expectations, the service customers receive, and customer loyalty to the retail pharmacy. The authors found that pharmacy location and price are the most important aspects in the market studied. In a later study (2014), they used the SERVQUAL scale to conduct similar research and found that of the five dimensions of the scale only the Assurance dimension met the customers' expectations. The results showed that the Tangibles, Reliability, Responsiveness, and Empathy dimensions did not reach the level expected by consumers, thus not positively affecting loyalty.

In another study, the relationship between satisfaction, trust, and loyalty in the retail pharmacy sector was investigated by Lira (2015), whose results indicated that satisfaction has a greater impact on customer loyalty than trust.

\section{Method}

Broadly speaking, this work is characterized as quantitative and descriptive. To achieve the objective of the study we conducted a literature review and questionnaire survey. The survey was carried out in a municipality with a population of 66,000 inhabitants located in Santa Catarina in the South Region of Brazil, on retail pharmacy customers in the city. The aim was to evaluate the relationship between brand reputation and customer 
loyalty in the retail pharmacy sector, considering both the most and least frequented pharmacies (brands) mentioned. The local retail pharmacy sector is made up of 35 regulated pharmacies (CRF, 2017), which according to the WHO (2014) represents a scenario of fierce competition, because the supply of pharmacies exceeds population demand by almost 500\%.

In this municipality, a sample of residents over 20 years old (defined as the study population) was selected through non-probability sampling (Virgillito, 2010). The field work was conducted in locations with considerable movement of people, between August 2 and September 22, 2017. The final sample was composed of 469 respondents.

The respondents were invited to evaluate, through the same instrument, two local retail pharmacy brands: the one they frequented most and the one they frequented least. The analysis instrument contains a section on the sample description and a section based on the variables presented in Table 1 . The scale variables were presented as statements and the dependent variable was presented as a semantic differential question, the answer to which ranged from 1 to 5 . The responses to each statement could range from 1 (totally disagree) to 5 (totally agree).

According to the literature our model is represented as follow:

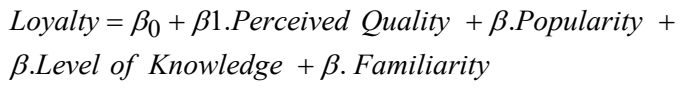

This study used multiple linear regression analysis, which, according to Virgillito (2010), is more flexible and allows for an examination of more than two variables that can influence the studied phenomenon, thus providing a greater technical range in terms of detecting relevant variables in relation to the studied object. In addition, the correlation (R) matrix was used, which according to Corrar, Paulo, and Dias (2009) shows the degree of association between the dependent variable and the independent variables. The closer the value is to -1 or +1 , the stronger the relationship. The $t$ test was also used, which according to Hair, Anderson, Tatham,

Table 1

\section{Analysis instrument variables}

\begin{tabular}{|c|c|c|c|c|}
\hline \multicolumn{4}{|c|}{ Dependent Variable } & \multirow{2}{*}{$\begin{array}{c}\text { Authors } \\
\text { Fornell et al. (1996); Johnson et al. } \\
\text { (2001); Pereira \& Bastos (2009); } \\
\text { Melo (2012); Gabriel et al. } \\
\text { (2013); Gabriel, Pelissari, \& } \\
\text { Oliveira (2014), Lira (2015) }\end{array}$} \\
\hline & ty to the retail & & Consideration of loyalty & \\
\hline Construct & Dimension & Predictors & Measurement variables & Authors \\
\hline \multirow[t]{4}{*}{ Brand Reputation } & Esteem & Perceived quality & $\begin{array}{l}\text { Prompt service } \\
\text { Willingness to help } \\
\text { Meeting deadlines } \\
\text { Problem solving } \\
\text { Variety of products }\end{array}$ & $\begin{array}{l}\text { Aaker (2009); Carvalho (2016); } \\
\text { Gerzema et al. (2009); Johansson } \\
\text { \& Ronkainen (2005); Machado } \\
\text { (2010); Sasikala (2013); Sampaio } \\
\text { (2017) }\end{array}$ \\
\hline & & Popularity & $\begin{array}{l}\text { Good reputation } \\
\text { Respect for the consumer } \\
\text { Brand appreciation } \\
\text { Brand consideration } \\
\text { Well known }\end{array}$ & $\begin{array}{l}\text { Aaker (2009); Carvalho (2016); } \\
\text { Gerzema et al. (2009); Johansson } \\
\text { \& Ronkainen (2005); Machado } \\
\text { (2010); Sasikala (2013); Sampaio } \\
\text { (2017) }\end{array}$ \\
\hline & Knowledge & Level of knowledge & $\begin{array}{l}\text { Grouping of reputation } \\
\text { Experience of usage } \\
\text { Knowledge about the brand } \\
\text { Attributes of the brand } \\
\text { Knowledge about brand products }\end{array}$ & $\begin{array}{l}\text { Aaker (2009); Costa (2009); } \\
\text { Freitas (2012); Kotler \& Keller } \\
\text { (2013); Lira (2015); Pereira \& } \\
\text { Bastos (2009); Ramos (2014); } \\
\text { Sampaio (2017); Sasikala (2013). }\end{array}$ \\
\hline & & Familiarity & $\begin{array}{c}\text { Thinking about this particular } \\
\text { brand } \\
\text { Feeling of familiarity } \\
\text { Brand recall } \\
\text { Brand product recall } \\
\text { Brand representation }\end{array}$ & $\begin{array}{c}\text { Aaker (2009); Costa (2009); } \\
\text { Freitas (2012); Kotler \& Keller } \\
\text { (2013); Lira (2015); Pereira \& } \\
\text { Bastos (2009); Ramos (2014); } \\
\text { Sampaio (2017); Sasikala (2013). }\end{array}$ \\
\hline
\end{tabular}


and Black (2005) evaluates the statistical significance of the difference between two sample means. The software used for the data analysis and treatment was IBM SPSS (Statistical Package for the Social Sciences).

The research sample is mostly composed of women (61\%). Regarding the age group, 29\% were between 20 and 29 years old; $31 \%$ were 30 to 39 years old; $19 \%$ were 40 to 49 years old; $15 \%$ were 50 to 59 years old; and $6 \%$ were above 60 years old. It is noteworthy that $61 \%$ had completed at least high school education, of which only $5 \%$ had completed higher education; $17 \%$ of the respondents had only completed elementary school. Concerning place of residence, all the districts of the municipality (17) were included in the survey, with the most cited district representing only $8 \%$ of the total sample. Among the respondents, $51 \%$ indicated that they went to a pharmacy at least once a month, while $20 \%$ did so twice a month, which represents a relative relationship with the type of retail examined.

\section{Results}

This section presents the results of the study. First, we analyzed the latent relationships between the variables using exploratory factor analysis, and then we evaluated the influence of the factors on the dependent variable.

\section{I Brand reputation factors for retail pharmacies}

Exploratory factor analysis (EFA) using the principal component method with direct Oblimin rotation was performed on the 20-item scale. In the first round of the EFA $(\mathrm{KMO}=0.876$; Bartlett test $=6497.674 ; \mathrm{df}=210$; $\mathrm{p}=0.000$ ), the following variables were removed because the communality was below the threshold of 0.5 : "this brand (pharmacy) is very well known," "the experience of using this brand (pharmacy) is a determining factor for my preference," and "I have a degree of familiarity with this brand (pharmacy)." In the second round of the EFA $(\mathrm{KMO}=0.869 ;$ Bartlett test $=6082.206 ; \mathrm{df}=136 ; \mathrm{p}=$ 0.000 ), the variable "this brand (pharmacy) has a good reputation" was deleted because the communality was below the threshold of 0.5 .

A new round of EFA $(\mathrm{KMO}=0.860$; Bartlett test $=5858.426 ; \mathrm{df}=120 ; \mathrm{p}=0.000)$ was performed and the items loaded on four factors, accounting for $78.14 \%$ of the total variance explained. As shown in Table 2, all the factors had a Cronbach's alpha score higher than 0.7. We identified four factors and labeled them as: Perceived Quality, Popularity, Level of Knowledge, and Familiarity.

The Perceived Quality dimension grouped the prompt service, willingness to help, meeting deadlines,

Table 2

EFA results $(n=469)$

\begin{tabular}{|c|c|c|c|c|c|}
\hline Factor and items & Factors Loading & Eigen-value & $\begin{array}{c}\text { Cronbach's } \\
\text { alpha }\end{array}$ & $\begin{array}{c}\text { Variance } \\
\text { explained (\%) }\end{array}$ & $\begin{array}{c}\text { Cumulative variance } \\
\text { explained }(\%)\end{array}$ \\
\hline Perceived Quality & & 5.890 & 0.876 & 36.810 & 36.810 \\
\hline prompt service & 0.683 & & & & \\
\hline willingness to help & 0.821 & & & & \\
\hline meeting deadlines & 0.871 & & & & \\
\hline problem solving & 0.816 & & & & \\
\hline variety of products & 0.845 & & & & \\
\hline Level of Knowledge & & 3.761 & 0.946 & 23.504 & 60.314 \\
\hline experience of usage & -0.923 & & & & \\
\hline knowledge about the brand & -0.924 & & & & \\
\hline attributes of the brand & -0.886 & & & & \\
\hline knowledge about brand products & -0.921 & & & & \\
\hline Familiarity & & 1.179 & 0.878 & 10.448 & 70.762 \\
\hline feeling of familiarity & 0.864 & & & & \\
\hline brand recall & 0.903 & & & & \\
\hline brand product recall & 0.879 & & & & \\
\hline brand representation & 0.854 & & & & \\
\hline Popularity & & 1.064 & 0.908 & 7.380 & 78.142 \\
\hline respect for the consumer & -0.860 & & & & \\
\hline brand appreciation & -0.907 & & & & \\
\hline brand consideration & -0.923 & & & & \\
\hline
\end{tabular}


problem solving, and variety of products variables. In the case of Popularity, the following variables were grouped: respect for the consumer, brand appreciation, and brand consideration. The Knowledge dimension grouped the measurement variables experience of usage, knowledge about the brand, attributes of the brand, and knowledge about brand products. Finally, the variables of the Familiarity dimension were feeling of familiarity, brand recall, brand product recall, and brand representation.

\subsection{Influence of brand reputation on customer loyalty to retail pharmacies}

As presented in the methodology, the respondents were asked about the retail pharmacies they most and least frequented. Both cases were tested using the linear regression technique and the group of variables from the EFA results. The value of each factor was calculated based on the average of the variables.

The results of the linear regression for the most frequented brands presented an absence of multicollinearity, the tolerance was greater than 0.1 , and the VIF was less than 10 (Table 4). The residuals were independent and the Durbin-Watson test returned a value of 1.604, which is within the acceptable parameters of 1.5 to 2.5 . The model presented a significant result for its use as a predictor of loyalty, presenting an explanatory power of $19.50 \%$. A summary of the model can be seen in the table 3 below.
It can be seen that the model's coefficient of determination showed an adjusted $\mathrm{R}^{2}$ value of 0.195 , an average explained variance size, according to Cohen (1988). In this sense, the evidence suggests that other unobserved factors may explain the unexplained variance in the model.

Regarding the dimensions of brand reputation and its impact on loyalty, the dimensions that showed significant relationships were: Popularity, Level of Knowledge, and Familiarity (table 4). The main predictor according to the standardized beta is Popularity. Familiarity had a negative relationship.

The research data show that popularity, as well as the level of knowledge, have positive and significant effects on loyalty. On the other hand, familiarity has a negative effect. This means that the more popular and known a brand is, the higher the customer loyalty; however, the effect is the opposite as consumers become more familiar with the brand. The level of knowledge indicates that the consumer not only knows the brand, but also understands what it stands for. Unlike awareness, knowledge cannot be built through exposures alone; instead, it is necessary to develop genuine customer intimacy with the brand. In this dimension, consumers internalize what the brand represents (Aaker, 2009; Gerzema et al. 2009; Machado, 2010).

It is important to know to what extent the brand is known to consumers, and what kind of relationship

Table 3

\section{Summary of the model}

\begin{tabular}{|c|c|c|c|c|c|c|c|c|c|c|}
\hline \multirow[b]{2}{*}{ Model } & \multirow[b]{2}{*}{$\mathbf{R}$} & \multirow[b]{2}{*}{$\mathbf{R}^{2}$} & \multirow{2}{*}{$\begin{array}{c}\text { Adjusted } \\
\mathbf{R}^{2}\end{array}$} & \multirow{2}{*}{$\begin{array}{l}\text { Standard } \\
\text { error of } \\
\text { estimate }\end{array}$} & \multicolumn{5}{|c|}{ Change statistics } & \multirow{2}{*}{$\begin{array}{l}\text { Durbin- } \\
\text { Watson }\end{array}$} \\
\hline & & & & & Change in $\mathbf{R}^{2}$ & Change in $F$ & gl1 & g12 & Sig. Change in $F$ & \\
\hline 1 & $0.449^{\mathrm{a}}$ & 0.202 & 0.195 & 1.071 & 0.202 & 29.289 & 4 & 464 & 0.000 & 1.604 \\
\hline
\end{tabular}

Note. a. Predictors: (Constant), familiarity, level_of_knowledge, perceived_quality, popularity; b. Dependent Variable: I consider myself to be loyal to this brand (pharmacy)

Table 4

\section{Coefficients $^{\mathrm{a}}$}

\begin{tabular}{|c|c|c|c|c|c|c|c|c|}
\hline & \multirow[t]{2}{*}{ Model } & \multicolumn{2}{|c|}{ Non-standardized coefficients } & \multirow{2}{*}{$\begin{array}{c}\begin{array}{c}\text { Standardized } \\
\text { coefficients }\end{array} \\
\text { Beta } \\
\end{array}$} & \multirow[t]{2}{*}{$\mathbf{T}$} & \multirow[t]{2}{*}{ Sig. } & \multicolumn{2}{|c|}{ Collinearity statistics } \\
\hline & & $\mathbf{B}$ & Standard error & & & & Tolerance & VIF \\
\hline \multirow[t]{5}{*}{1} & (Constant) & 2.320 & 0.342 & & 6.790 & 0.000 & & \\
\hline & Perceived_quality & 0.002 & 0.082 & 0.001 & 0.027 & 0.979 & 0.728 & 1.375 \\
\hline & Popularity & 0.224 & 0.061 & 0.192 & 3.685 & 0.000 & 0.631 & 1.585 \\
\hline & Level_of_knowledge & 0.321 & 0.055 & 0.301 & 5.890 & 0.000 & 0.659 & 1.518 \\
\hline & Familiarity & -0.240 & 0.065 & -0.176 & -3.694 & 0.000 & 0.756 & 1.323 \\
\hline
\end{tabular}

Note. a. Dependent Variable: I consider myself to be loyal to this brand (pharmacy) 
they have with it. Knowledge is the extension of consumer awareness about the brand, as well as their understanding of its identity. It is through knowledge that we can assess consumers' brand knowledge and familiarity. The relationship between consumer understanding and what the brand stands for is measured by knowledge since this is not only achieved through the media; it cannot be bought, it must be achieved by the brand (Kotler $\&$ Keller, 2013; Ramos, 2014; Sasikala, 2013). According to the research data and in line with literature on the subject, it is assumed that the level of knowledge is of great importance to the customer relationship and consequently to customer loyalty.

In addition, the findings are consistent with the work of Johansson and Ronkainen (2005), which indicates that a brand needs to attain a certain level of familiarity to achieve consumer loyalty. It is also reported by the authors that the evaluation should consider measures such as respect and perceived quality, which in this research were not statistically significant and hence not evaluated.

Other aspects may differ by country and culture, such as perceived quality and popularity. Depending on the local culture, ways can be found to change consumers' perceptions of quality and increase the popularity of the brand, thus creating greater loyalty (Ramos, 2014; Sampaio, 2017). In light of the above, for the most frequently visited pharmacies (brands) an increased level of knowledge and popularity may have a positive impact on loyalty. The model equation for the most frequented brands is:

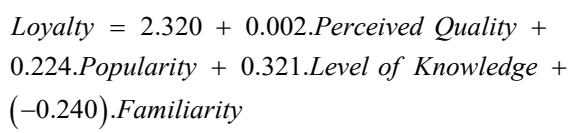

The results of the linear regression for the least frequented brands presented an absence of multicollinearity, the tolerance was greater than 0.1 , and the VIF was less than 10 (Table 6). The residuals were independent and the Durbin-Watson test returned a value of 1.567 , which is within the acceptable parameters of 1.5 to 2.5 . The model presented a significant result for its use as a predictor of loyalty, presenting an explanatory power of $28.80 \%$. The summary of the model can be seen in the table 5 below.

In the same way as was analyzed for the most frequented brands, it is also observed that the model's coefficient of determination presented an adjusted $\mathrm{R}^{2}$ value of 0.288 , an average explained variance size, according to Cohen (1988). In this sense, the evidence suggests that other unobserved factors may explain the unexplained variance in the model.

Regarding the dimensions of brand reputation (for the least frequented ones) and its impact on loyalty, the dimensions that showed significant relationships were: Level of Knowledge and Familiarity (table 6).

Table 5

\section{Summary of the model}

\begin{tabular}{|c|c|c|c|c|c|c|c|c|c|c|}
\hline \multirow[b]{2}{*}{ Model } & \multirow[b]{2}{*}{$\mathbf{R}$} & \multirow[b]{2}{*}{$\mathbf{R}^{2}$} & \multirow{2}{*}{$\begin{array}{c}\text { Adjusted } \\
\mathbf{R}^{2}\end{array}$} & \multirow{2}{*}{$\begin{array}{c}\text { Standard } \\
\text { error of } \\
\text { estimate }\end{array}$} & \multicolumn{5}{|c|}{ Change statistics } & \multirow{2}{*}{$\begin{array}{l}\text { Durbin- } \\
\text { Watson }\end{array}$} \\
\hline & & & & & Change in $\mathbf{R}^{2}$ & Change in $F$ & gl1 & g12 & Sig. Change in $F$ & \\
\hline 1 & $0.542^{\mathrm{a}}$ & 0.294 & 0.288 & 0.767 & 0.294 & 48.358 & 4 & 464 & 0.000 & 1.567 \\
\hline
\end{tabular}

Note. a. Predictors: (Constant), familiarity, level_of_knowledge, perceived_quality, popularity; b. Dependent Variable: I consider myself to be loyal to this brand (pharmacy)

Table 6

\section{Coefficients $^{\mathrm{a}}$}

\begin{tabular}{|c|c|c|c|c|c|c|c|c|}
\hline & \multirow[t]{2}{*}{ Model } & \multicolumn{2}{|c|}{ Non-standardized coefficients } & \multirow{2}{*}{$\begin{array}{c}\begin{array}{c}\text { Standardized } \\
\text { coefficients }\end{array} \\
\text { Beta } \\
\end{array}$} & \multirow[t]{2}{*}{$\mathbf{T}$} & \multirow[t]{2}{*}{ Sig. } & \multicolumn{2}{|c|}{ Collinearity statistics } \\
\hline & & B & Standard error & & & & Tolerance & VIF \\
\hline \multirow[t]{5}{*}{1} & (Constant) & 0.341 & 0.113 & & 3.007 & 0.003 & & \\
\hline & Perceived_quality & 0.061 & 0.049 & 0.060 & 1.255 & 0.210 & 0.659 & 1.518 \\
\hline & Popularity & 0.092 & 0.056 & 0.088 & 1.646 & 0.101 & 0.533 & 1.877 \\
\hline & Level_of_knowledge & 0.226 & 0.060 & 0.203 & 3.773 & 0.000 & 0.525 & 1.906 \\
\hline & Familiarity & 0.335 & 0.057 & 0.298 & 5.885 & 0.000 & 0.592 & 1.689 \\
\hline
\end{tabular}

Note. a. Dependent Variable: I consider myself to be loyal to this brand (pharmacy) 
In this case, for level of knowledge and, particularly, familiarity, we observe a positive and significant impact on loyalty. The familiarity results had an important impact on loyalty, which is consistent with the studies by Johansson and Ronkainen (2005), in that the brand needs to reach a certain level of familiarity to achieve customer loyalty. This level, according to the research data, is very strong and significantly present in the brands (pharmacies) said to be the least frequented. The results showed that the model for the least frequented pharmacy has a higher explanatory power than the one for the most frequented pharmacy. The model equation for the least frequented pharmacy is:

Loyalty $=0.341+0.061$ Perceived Quality +

0.092.Popularity + 0.226.Level of Knowledge +

0.335.Familiarity

\section{Conclusion}

With the increasing competition in the retail pharmacy sector, intensified by the expansion of stores, the increased market share of large chains, as well as the similarity of the sector's products, among other influencing factors, companies need to find ways to remain competitive and active in the market.

The present study focused on this context and its purpose was to evaluate the relationship between the reputation of the retail brand and customer loyalty in the retail pharmacy sector.

The findings of the research showed that the items that most influence customer loyalty to retail pharmacies are popularity, level of knowledge, and familiarity for the most frequented brands (pharmacies), while for the least frequented brands (pharmacies) those items are the level of knowledge and familiarity.

These findings show a positive relationship between brand reputation and customer loyalty, that is, the better the brand reputation, the greater the loyalty towards the pharmacy. The results also showed that there is a difference in the respondents' perception regarding the pharmacy (brand) they frequented the most and the pharmacy they frequented the least. The least frequented brands have a lower level of loyalty, which was expected; however loyalty to them is more constant than loyalty to the most frequented brands. This means that a brand with fewer loyal customers, despite having a lower possibility of acquiring new customers through brand reputation, is less likely to lose the customers it has already won.
These latest findings provide an important contribution to the theory, since previous studies that have analyzed the role of reputation in customer loyalty have only verified the role of the brands that were most relevant within the market researched. In the case of this study, in addition to the findings for the most relevant brands, variables were also identified that influence loyalty to the least relevant brands.

For future studies we suggest reapplying the research in other geographic markets, as well as in other types of retail, including where there is a greater or lesser degree of differentiation. Other types of statistical analysis could also be applied in future research on the subject, such as structural equation modeling, and qualitative research could also provide other findings that are relevant to the theme. Other investigations could further the understanding of how to increase familiarity so that it has a positive effect, as well as clarifying consumers' perception of quality in the retail pharmacy sector.

\section{References}

Aaker, D. A. (2009). Building Strong Brands. São Paulo: Bookman.

Aaker, D. A. (2012). Win the brand relevance battle and then build competitor barriers. California Management Review, 54(2), 43-57.

Aaker, D. A. (2014). Aaker on branding: 20 principles that drive success. New York: Morgan James.

Balmer, J. M. (2012). Strategic corporate brand alignment: Perspectives from identity based views of corporate brands. European Journal of Marketing, 46(7/8), 1064-1092.

Bell, D. R. (2014). Location Is (Still) Everything: The Surprising Influence of the Real World on How We Search, Shop, and Sell in the Virtual One. Boston, New York: New Harvest, Houghton Mifflin Harcourt

Carvalho, G. P. (2016). Valor da marca baseado no consumidor: Impactos no desempenho de produtos (Dissertação de Mestrado) FACE - Faculdade de Economia, Administração, Contabilidade, PPGA - Programa de Pós-graduação em Administração, PPGA - Mestrado em Administração, Universidade de Brasília - UNB, Brasília, Distrito Federal, Brasil. Recuperado de https://repositorio.unb. br/handle/10482/19187 
Conselho Federal de Farmácias. (2018). Informação de Mercado. Brasília: Autor. Retrieved from http://cff.org.br/ notícia.php?id=3879\&titulo=Farm\%C3\%A1cias+de+elite.

Conselho Regional de Farmácia. (2017). Número de estabelecimentos. São Paulo: Autor. Retrieved from http:// crfsc.gov.br/seccionais/seccional-vale-do-itajai/.

Corrar, L. J., Paulo, E., \& Dias, J. M., Fo. (2009). Análise multivariada: Para os cursos de administração, ciências contábeis e economia. São Paulo: Atlas.

Cohen, J. (1988). Statistical power analysis for the behavioral sciences (2nd ed.) Erlbaum: New Jersey.

Costa, M. I. D. S. F. (2009). Valor da marca no fitness: Estudo da imagem e das associaçóes à marca na lealdade (Tese de mestrado). Instituto Superior de Ciências do Trabalho e da Empresa - ISCTE, Lisboa, Portugal. Retrieved from https://repositorio.iscte-iul.pt/handle/10071/1691

Demo, G. (2014) B2C Market: Development of a CRM scale. In A., Ghorbani (Ed.), Marketing in the cyber era: Strategies and emerging trends (Chapter 6, 85). United States: Business Science Reference.

Feldman, P. M., Bahamonde, R. A., \& Velasquez Bellido, I. (2014). A new approach for measuring corporate reputation. Revista de Administração de Empresas, 54(1), 53-66.

Fernandez, A. I., Lara, P. R., Ugalde, M. C., Sisodia, G. S. (2018). Distinctive competencies and competencybased management in regulated sectors: A methodological proposal applied to the pharmaceutical retail sector in Spain. Journal of Retailing and Consumer Services. 42, 29-36.

Fetscherin, M., \& Usunier, J. C. (2012). Corporate branding: An interdisciplinary literature review. European Journal of Marketing, 46(5), 733-753.

Fonseca, A. R. R. (2015). Indicaçāo geográfica como recurso estratégico: Reputação e julgamento de marca do Porto Digital-Recife, PE (Dissertação de mestrado). Universidade Federal de Sergipe, UFS, Sergipe, SE, Brasil. Retrieved from http://bdtd.ibict.br/vufind/Record/UFS-2_6e780 df3770c0b14b2c36b87bdc66c83

Foreman, J., \& Argenti, P. A. (2005). How corporate communication influences strategy implementation, reputation and the corporate brand: An exploratory qualitative study. Corporate Reputation Review, 8(3), 245-264.

Fornell, C., Johnson, M. D., Anderson, E. W., Cha, J., \& Bryant, B. E. (1996). The American customer satisfaction index: nature, purpose, and findings. The Journal of Marketing, 60(4), 7-18.

Foroudi, P., Dinnie, K., Kitchen, P. J., Melewar, T. C., \& Foroudi, M. M. (2017). IMC antecedents and the consequences of planned brand identity in higher education. European Journal of Marketing, 51(3), 528-550.

Foroudi, P. (2019). Influence of brand signature, brand awareness, brand attitude, brand reputation on hotel industry's brand performance. International journal of hospitality management, 76, 271-285.

Freitas, M. A. C. (2006). Estratégias empresariais do setor varejista de produtos farmacêuticos de Belo Horizonte (Dissertação de Mestrado). Universidade Federal de Minas Gerais - UFMG, Belo Horizonte, BH, Brasil. Retrieved from https://repositorio.ufmg.br/handle/1843/ CSPO-6VZQTU

Freitas, M. B. R. (2012). Valor da marca: Um estudo sobre a problemática de sua evidenciação contábil no Brasil (Dissertação de Mestrado). Universidade do Estado do Rio de Janeiro -UERJ, Rio de Janeiro, RJ, Brasil. Retrieved from https://bdtd.ibict.br/vufind/Record/ UERJ_a40b42973ea0b08fbce8dd4b069c0dc5

Gabriel, M. O., Pelissari, A. S., \& Oliveira, M. P. V. (2013). Percepção e Fidelização: Um estudo dos clientes de farmácias na cidade de Vitória (ES). Revista Gestão \& Conexöes, 2(1), 187-209.

Gabriel, M. O., Pelissari, A. S., \& Oliveira, M. P. V. (2014). Relacionamento com clientes do setor farmacêutico em Vitória-ES: uma análise dos impactos do nível de serviço esperado e ofertado na fidelizaçáo dos clientes. REAdRevista Eletrônica de Administração, 20(1), 64-89.

Gerzema, J., Lebar, E., \& Rivers, A. (2009). Measuring the contributions of brand to shareholder value (and How to Maintain or Increase Them). Journal of Applied Corporate Finance, 21(4), 79-88. 
Golgeli, K. (2014). Corporate reputation management: The sample of Erciyes University. Procedia-Social and Behavioral Sciences, 122, 312-318.

Hamzah, Z. L., Alwi, S. F. S., \& Othman, M. N. (2014). Designing corporate brand experience in an online context: A qualitative insight. Journal of Business Research, 67(11), 2299-2310.

Hair, J. F., Jr, Anderson, R. E., Tatham, R. L., \& Black, W. C. (2005). Análise multivariada de dados (6th ed.). São Paulo: Bookman.

Hermes, L. C. R., Cruz, C. M. L., \& Santini, L. (2016). Vantagens competitivas do mix de varejo sob a ótica da VRIO: Um estudo de caso em um supermercado independente. REMark, 15(3), 373.

Johansson, J. K., \& Ronkainen, I. A. (2005). The esteem of global brands. Journal of Brand Management, 12(5), 339-354.

Johnson, M. D., Gustafsson, A., Andreassen, T. W., Lervik, L., \& Cha, J. (2001). The evolution and future of national customer satisfaction index models. Journal of Economic Psychology, 22(2), 217-245.

Knox, S., \& Bickerton, D. (2003). The six conventions of corporate branding. European Journal of Marketing, 37(7/8), 998-1016.

Kotler, P., Bowen, J., \& Makens, J. (1999). Marketing for hospitality and tourism, upper saddle river. New Jersey: Prentice Hall.

Kotler, P., \& Keller, K. L. (2013) Administração de marketing. São Paulo: Pearson Prentice Hall.

Kumar, V., Ananda, A., \& Song, H. (2017). Future of retailer profitability: An organizing framework. Journal of Retailing, 93(1), 96-119.

Lira, A. M. F. (2015). Relação entre satisfação, confiança e fidelidade para os consumidores de farmácias e drogarias em Curitiba. Revista de Ciências Gerenciais, 12(14), 149-166.

Louro, M. J. S. (2000). Modelos de avaliação de marca. Revista de Administração de empresas, 40(2), 26-37.

Machado, M. (2010) Análise de cluster dos indicadores de brand equity em marcas globais de cosméticos (Dissertação de Mestrado). Fundação Instituto Capixaba de Pesquisas em Contabilidade, Economia e Finanças - FUCAPE, Vitória, Espirito Santo, Brasil.

Melo, J. A. D. (2012). Gestão Pública Participativa: Avaliação do Orçamento Participativo da Prefeitura de Fortaleza (Tese de Mestrado). Faculdade de Economia da Universidade de Coimbra - FEUC, Coimbra, Portugal. Retrieved from https://estudogeral.sib.uc.pt/handle/10316/18208

Molina, R., Israel, R., \& Ampudia Sjogreen, D. E. (2018). Factores de competitividad empresarial en el Sector Comercial. RECITIUTM, 4(1), 16-32.

Morgan, R.B. \& Hunt, S. (1999) Relationship-based competitive advantage: The role of relationship marketing in marketing strategy. Journal of Business Research, 46 (3), 281-290.

Mukerjee, K. (2018). The impact of brand experience, service quality and perceived value on word of mouth of retail bank customers: Investigating the mediating effect of loyalty. Journal of Financial Services Marketing, 23(1), 12-24.

Oliver, R. L. (2014). Satisfaction: A behavioral perspective on the consumer. New York: Routledge.

Parker, J. R., Lehmann, D. R., Keller, K. L., \& Schleicher, M. G. (2018). Building a multi-category brand: When should distant brand extensions be introduced? Journal of the Academy of Marketing Science, 46(2), 300-316.

Payne, A. (2006). Handbook of CRM: Achieving excellence in customer relationship. Amsterdam: Elsevier.

Pereira, P. F. P., \& Bastos, F. C. (2009). Um estudo sobre a fidelizaçáo de clientes a partir de estratégias de marketing de relacionamento no segmento de farmácias e drogarias. SEGET-Simpósio de Excelência em Gestão e Tecnologia, 1-15.

Pinheiro, I. N. (2006). Gestão de satisfação e fidelidade do cliente: um estudo dos fatores que afetam a satisfação e fidelidade dos compradores de automóveis (Dissertação de Mestrado). Universidade Federal do Rio Grande do Norte - UFRGN, Rio Grande do Norte, Brasil. Retrieved from https://repositorio.ufrn.br/handle/123456789/15099

Ramos, A. (2014). As implicaçôes dos sentimentos das pessoas no modelo de brand equity (Dissertação de Mestrado). Instituto 
Superior de Gestão - ISG, Lisboa, Portugal. Retrieved from https://comum.rcaap.pt/bitstream/10400.26/12954/1/ Tese_entrega_24Junho2014_versaofinal.pdf

Reichheld, F. F., \& Schefter, P. (2000). E-loyalty: your secret weapon on the web. Harvard business review, 78(4), 105-113.

Samawi, J. (2017). Marketing relationship as a source for achieving competitive advantage. International Journal of Business and Social Science, 8(8), 109-118.

Sampaio, M. A. (2017). O Poder do branding nas organizaçôes: A influência do valor da marca Aldi na escolha do consumidor (Dissertação de Mestrado). Instituto Superior de Gestão - ISG, Lisboa, Portugal. Retrieved from https://docplayer.com.br/59001353-O-poder-dobranding-nas-organizacoes-a-influencia-do-valor-damarca-aldi-na-escolha-do-consumidor.html

Santos, R. A., \& Anjos, M. A. D. (2018). Marketing de relacionamento para fidelização do cliente: Um estudo de caso em uma empresa do varejo na cidade de Monte Carmelo-MG. Revista GeTeC, 7(17), 81-96.

Sasikala, D. (2013). Brand asset valuator-measuring brand value. International Journal of Social Science \& Interdisciplinary Research, 2(6), 133-138.

Scussel, F. B. C., \& Demo, G. (2016). Personalidade de marca: Itinerários da produção nacional e agenda de pesquisa. REMark, 15(3), 340.
Silva, M., Vasconcelos, M. C. R. L., Jeunon, E. E., \& Duflot, S. (2016). Knowledge enablers and strategies of survival and development used to increase competitiveness: A case study in a multinational company of the food sector/Capacitadores do conhecimento e estratégias de sobrevivência e avanço para o aumento da competitividade: Estudo em uma multinacional do setor alimentício. Revista Ibero-Americana de Estrategia, 15(2), 108-122.

Srivastava, M., Arora, S., Lakhotia, S., \& Tripathy, S. (2015). Measuring brand trust using brand equity model in oral care product category. International Journal of Multidisciplinary Approach \& Studies, 2(6).

Srour, R. H. (2003). Ética empresarial: A gestão da reputação. São Paulo: Campus.

Thomas, S. (2013). Linking customer loyalty to customer satisfaction and store image: A structural model for retail stores. Decision, 40 (1-2), 15-25.

Virgillito, S. B. (2010). Pesquisa de marketing: uma abordagem quantitativa e qualitativa. São Paulo: Saraiva.

World Health Organization (2017). Recomendaçôes. Retrieved from http://www.who.int/en/

Zeithaml, V. A., Bitner, M. J., \& Gremler, D. D. (2014). Marketing de Serviços-: A Empresa com Foco no Cliente (6a ed.). Porto Alegre, RS: AMGH Editora. 


\section{Financial support:}

None

\section{Conflicts of interest:}

None

\section{Copyrights:}

RBGN owns the copyrights of this published content.

\section{Plagiarism analysis:}

RBGN performs plagiarism analysis on all its articles at the time of submission and after approval of the manuscript using the iThenticate tool.

\section{Authors:}

1. Péricles Ewaldo Jader Pereira, Master in Administration -Management, Internationalization, and Logistics (2017), Balneário Camboriú, Brazil.

E-mail: peckjader@gmail.com

2. Carlos Marcelo Ardigó, PhD in Production Engineering (2013), Federal University of Santa Catarina (UFSC), Itajaí, Brazil.

E-mail: marcelo.ardigo@univali.br

3. Pablo Flôres Limberger, PhD in Tourism and Hospitality (2015), University of Vale do Itajaí (2015), Balneário Camboriú, Brazil.

E-mail: pablofl@univali.br

\section{Authors' Contributions:}

$\mathbf{1}^{\text {st }}$ author: Definition of research problem; Development of hypotheses or research questions (empirical studies); Development of theoretical propositions (theoretical work); Definition of methodological procedures; Data Collection; Literature review; Statistical analysis; Analysis and interpretation of data; Critical revision of the manuscript; Manuscript writing.

$2^{\text {nd }}$ author: Definition of research problem; Development of hypotheses or research questions (empirical studies); Development of theoretical propositions (theoretical work); Definition of methodological procedures; Data Collection; Literature review; Statistical analysis; Analysis and interpretation of data; Critical revision of the manuscript; Manuscript writing.

$3^{\text {rd }}$ author: Definition of research problem; Development of hypotheses or research questions (empirical studies); Development of theoretical propositions (theoretical work); Definition of methodological procedures; Data Collection; Literature review; Statistical analysis; Analysis and interpretation of data; Critical revision of the manuscript; Manuscript writing. 